\title{
ŚRĪ SWĀMINĀRĀYAṆA'S POSITION ON ŚABDAPRAMĀṆA AND ŚRUTI: questions of epistemic and theological validity ${ }^{1}$
}

\author{
A study of the pramānas is an indispensable prolegomena \\ to all metaphysical investigation (pramāṇādhīna prameya sthitiḥ) - \\ S M Śrīnivasa Chari (1976:19). \\ Purushottama Bilimoria, $\mathrm{PhD}$ \\ pbilimoria@qtu.edu
}

Abstract

This paper argues that Śrī Swāminārāyaṇa espoused a position on the pramāna-s (means of knowing), and his theory was that among these it is śabdapramanna that is the important and authoritative pramāna. However, in delineating the precise sources and textual authority that fall within the ambit of śabdapramāna, he privileged mostly the Smrti texts, along with Vedānta and Bhagavadgītā commentaries, to which was added later his own the Gujarati text Vachanāmrut, as canonical texts of the particular Sampradāya. In so doing he would be seen to be departing somewhat from classical positions on authoritative scriptures, in particular of Śańkara and, to an extent, Rāmānuja, for whom Śruti ('revealed') and Smṛti ('recollected') scriptures respectively denote quite different genre of texts, and with graded degree (rather kind) of authority; these could even be apaurușeya, authorless scriptures. The paper analyses the precise reasons for Swāminārāyaṇa to arrive at this qualified position and the arguments he garnishes toward this doctrinal hermeneutic, concluding with comments on his slight departure from the classically accepted understanding of śabdapramāna where scriptural sources are the preeminent concern with a somewhat different trajectory.

\section{Introduction}

Swāminārāyaṇa lived from 1781 - 1830; he was born in Uttar Pradesh. While his birthname was Ghanshyam, at age 11 he adopted the name Nilkanth Varni and set out on a seven-year long pilgrimage across India. As his ascetic profile grew he came to be known as Sahajānand Swami. From 1802, after taking over the Uddhava Sampradāya from his Guru Rāmānand, and because his followers believed him to be an incarnation of God, he came to be known as Śrī Swāminārāyaṇa. His goal seemed to be, as with a number of early Hindu reformists of the period, to pave new vistas for a Hindu 
renascence and to revive what he understood to be the central tenets of Hinduism, namely, dharma, ahimșā (non-injury), and brahmācārya (sexual and moral continence). This was also a period of the steady expansion of British trading prowess and gradually colonial power in the subcontinent. However, Shahajanand-Swāminārāyaṇa did not pit himself or his order against the British Rāj; instead, he maintained a harmonious relationship with the British administrators and even obtained benefits from the Lords he had occasional meetings with: such as, land for building the sect's first temple in Ahmedabad, and public endorsement for undertaking affirmative reforms for the poor and for women. In 1826 he wrote Śikșāpatri, apparently in Sanskrit (which is not extant), and was translated under his supervision into Gujarati, which set out in 212 verses the basic tenets of the Samparadāya with an emphasis on disciplined moral living. It is the Vachanāmrut, which was composed in Gujarati in 1819 from dialogues he held with his five prominent disciples, that laid down the philosophical doctrines and epistemological foundations that Śrī Swāminārāyaṇa had conceived in the course of thinking about the question of authenticity within the doctrinal framework of Hindu theology and the authoritative sources that would once and for all legitimize the Sampradāya's membership within Hindu orthodoxy - and protect it against possible charges of being a nāstika aberration, like the Cārvāka-s. This question falls in part within the ambit of pramānavāda, theoretical quest for valid knowledge, its means and validation. This is the subject matter of the paper. The Vachanāmrut itself has come to be regarded as the śabdapramāna or authoritative text in the tradition.

This paper argues that Śrī Swāminārāyaṇa held to a strong position on the pramāna-s (means of knowledge), and his theory, consistent with the asstikatva or orthodox predilection, was that śabdapramāna is the pre-eminent and authoritative pramāna. However, in delineating the precise sources and textual authority that fall within the compass of śabdapramāna, he appears to have privileged mostly the Smrti texts, along with commentaries on primary Vedānta texts and the Bhagavadgītā, and his own Gujarati text Vachanāmrut as canonical and authoritative texts of the Sampradāya. In so 
doing he would be seen to be departing somewhat from classical positions on authoritative scriptures, in particular of Śan்kara and, to an extent, Rāmānuja, for whom Śruti ('revealed') and Smrti ('recollected') scriptures respectively bring together quite different genres of texts, and with differential degrees - if not difference in kind - of authority. Although it is be noted that during Śrī Swāminārāyaṇaa's time and under his oversight his close disciples Muktanand and Gopalanand composed bhāṣya-s on the Brahmasūtra-s of Bādarāyaṇa as part of the prasthāna-trayī that, at least, in Vedānta is considered to be the foundational pillars of sacral authority. Closer to our times, in 2007, Bhadreshdas Swami of the BAPS Swāminārāyaṇa Sanstha completed commentaries in Sanskrit on the prasthāna-trayī (comprising the Upaniṣads, Bhagavadgītā, and the Brahmasūtra-s), thereby clinching a claim to a distinct darśana status within the grand Vedānta matrix. It is supposed to establish the BAPS Sanstha firmly within the folds of the Vedānta sampradāya, but since each of the major ācārya-s had established their own individuated sampradāya it would be difficult to affirm definitively which of the sampradāya's in the hugely amorphous Vedānta geneaology the BAPS Sanstha locates its lineage. Although I believe the argument made was that Bhagwan Swāminārāyaṇa's Akshar-Purushottam Darshan is the first new independent school of Vedānta to be founded since the $16^{\text {th }}$ century. ( see Yajnik ; R. Dave ) That may be true, but the grounds for this claim does not necessarily have to come from a set of commentaries completed in 2007 - without concomitant recognition by the other Sansthas. It is not clear how such a recognition comes about, but since the Swāminārāyaṇa's AksharPurushottam Darshan is distributed over a number of incommensurate Sansthas, it would be difficult for scholars to understand this claim coming from a solo Sanstha on the basis of its own internally-curated work. One other curious lacuna in these modernday commentarial work is that it excludes the pūrvapakșa, the adversarial voice ${ }^{2}$, which elision goes against the grain of classical commentarial tradition (indeed of all philosophizing in India), and could be said to fall short of the task of bringing out in the dialectical mode the strength of the Sanstha's position with arguments answering to actual and possible objections from one's perceived opponents or detractors, or rivals 
within the larger Sampradāya (e.g. the alternative interpretation of the Vadtal Sanstha and the motley of other Swāminārāyaṇa Sampradāya sansthas). That elision notwithstanding in the BAPS project, the paper asks whether the production of a new set of commentaries which replaces the earlier set from the time of Swāminārāyaṇa (that, incidentally did include the participation of the pūrvapakșa), in and of itself is sufficient to settle the central question about the establishment of an argument for śabdapramāna in respect of Śruti, and what such an argument or theory might look like. As well, whether this sanguine move would be acceptable to the other forty-odd sects within the larger Sampradāya that pre-dates and post-dates the BAPS Sanstha, such as again - as the Vadtal (Vartal) Sanstha.

The caveat taken up in this paper is that it is an understanding among Indian philosophers that one's overarching epistemology (theory of knowledge) - that is, the decision as to just which scriptural texts are admitted as (śabda-)pramāna, and therefore authoritative for their dārśanic sampradāya (philosophical school) - has a direct bearing on exactly the kind of metaphysical and theological positions they end up with. If perception was the only valid means of knowing accepted in a school - e.g. among the Cārvākas or naturalists - then their metaphysics would be restricted to empirical reality or the ontology of natural kinds. Taking another example, if Vedas and within that the Brāhmanas-s were taken as the preeminent form of śabdapramāṇa qua Śruti in school X (such as the Mīmāṃsā), then it is more than likely that the school will underscore the value and imperative of ritual performance (yajña): every sentence in the nominated Śruti will be read as a vidhi (prescriptive statement). If it is the Upanișad-s then quite as likely belief in a formless (nirguna), non-emergentist, impersonal Brahman may be the end-point of their metaphysical theology (Black 2018). But if, say for argument's sake, Manusmrti or the Dharmaśāstras were adopted as the canonical texts, then for that system the ontology might end up being one that is predicated on moral and legal normative order of things within a set social reality. This latter metaphysical and to that extent (in this context) the theological ramification in relation to Swāminārāyaṇa's position will be discussed in the second part of the paper. First, though, a brief 
introduction to the theory of pramāna (known as pramānavāda), with a specific focus on the discourse of śabdapramāna, as the key element for the present purposes.

\section{The Pramāna-s}

In classical Indian thinking, the discussion and disputation over the means of investigation preceded all discourse about the nature of reality, in both its phenomenal and ultimate senses or reaches. Epistemology determines the scope of metaphysics (pramānāāhin̄ā prameya sthitihh). This was expressed in terms of the wide-ranging discourse on what has been referred to as pramāna, which translates as 'sources or means of knowledge'. In the main, pramāna deals with the question of the possibility and grounds of valid knowledge. Questions seen to be relevant for any theory of knowledge to be viable are raised within the ambience of the branch of thought known as pramānavāda, which has its cognate in Western thought in the subdiscipline of 'epistemology'.

As is well-known to all students of Indian epistemology, pramāna has three basic functions: first, pramāna as a karana or instrumental means that becomes effective as a source of knowledge, which is delivered through a concatenation of causal conditions (kāraṇas) and efficacious factors (vyāparas); secondly, pramāna as a means of scrutinizing, evaluating through ratiocination the understanding or knowledge-claim derived through the source; thirdly, as prāmānya, the 'measurement' in terms of the criteria for 'truth' or 'falsity', which is characterized as the problem of validity. (Bilimoria 2018b). Together these constitute the grounds for the possibility of knowing. ${ }^{3}$ The structure of pramāna is best illustrated through this diagrammatic representation:

\section{Phenomenological structure}

Jn. Jñ̄ana Cognition

Knowing - awareness of something a) causal - what brings about

b) logical/ epistemic structure - what gives it disclosing/-revealing power 
General Rule for all Events : $\mathrm{X}$ is caused by $\mathrm{Y}, \mathrm{Z},+$ null factors

$J n$ is caused by conditions

$J n$-> "blob"-> unformed -> seeking, intending clarity, substance, qualities

$J n<$ indeterminate, pre-reflective $\rightarrow \quad$ determinant, undefined prameya (object)

\section{Logical Structure}

1. Conditions that cause also illumine/ light up

2. Extra conditions necessary i.e. not sufficient sense- organs make contact. -Mind receives contents (noema) (concepts)

-Consciousness sent by soul, ātmā to light up

-Object appears as prameya (defined perception)

Now it is usual for most schools of Indian thought to accept at least three pramānas as legitimate and authoritative. The three pramāṇas are: pratyakṣa (perception), anumāna (inference), and śabdapramāna (verbal or scriptural testimony). (Bilimoria 1980; 2008). We shall say a little on each pramāna, beginning with pratyakșa.

\section{Pratyakșa (perception)}

Experience, it would appear, shows us that perception, by which is meant 'visual seeing', is the first and perhaps the primary - though by no means definitive or exhaustive source of our knowledge, since sense-experience, of which 'seeing' is a part, is the most common means of awareness of the external world: the given in empirical experience. The cognition derived through perception is the same kind of jñāna or cognition that all the other pramānas also deliver, but these will vary in degrees in respect of the content and the factors that 'lend' them the mark (guna) of validity. A veridical perception is one in which the noetic or phenomenal properties of the jñāna obtained conforms to the properties in the substrate of the object that is accessed by the senses and cognized in the mind. Thus one does not see the property of 'blazing fire' when the eyes or other 
senses encounter water. That it is water and not fire may be confirmed if the substance quenches one's thirst; the self-evident truth delivered by pratyakșa is thereby corroborated. (Bilimoria 1980). However, as important as it is, pratyakșa may fail to give us knowledge of the absence (or what some might call 'negative presence') of objects encountered through our sensory experience (which may call for a separate pramāna all its own: abhāva; Bilimoria 2016), and most definitely on moral matters as well as the possibilities that lay beyond the empirical, i.e. in the transcendental domain. And so the limitations of pratyakșa necessitates consideration of other pramāna-s.

\section{Anumāna (inference)}

When an object or event is not present to the senses but some other seemingly related object or episode is in sight, then attempt is made to relate the two episodes to some structure. Here, reasoning, as a mode of ordered thinking, becomes imminent. ${ }^{4}$ And this structure is provided by the pramāna of anumāna, usually translated as 'inference'. Inference comes in a variety of kinds: inductive - from particulars to general -, deductive - from general to particular - and modal - reasoning from abstract possibility or probability to an actual instance. Anumāna thus functions as a formal process for deducing or inferring novel understanding from the interrelations of facts, objects or events perceived through such other sources as are available, in particular pratyakșa (but also abhāva, cognition of absence; upamāna, analogy, and arthapatti, presumption). The Nyāya ('Logic) school developed a form of syllogistic structure to ground the soundness and validity of the inferential process (which combines induction and deduction), as illustrated with the following example.

There is fire on the mountain

(Because) there is smoke perceived on the mountain

Where there is fire there is smoke (vyāpti), as in the kitchen stove,

There is smoke

Therefore there is fire. 
Logic, or naya, is developed as an extension and an aid to the wider capabilities of anumāna, with a focus on sophisticated reasoning, adherence to rules of debates, while at the same time the capacity to discern contradictions and certain fallacies inherent in working up an argument, or charting out the fallibility of even the most cogent argument by demonstrating its invalidity (in a process known as reductio, whereby the presuppositions turn out at base to be vacuous, fallacious or simply false). One weakness of the syllogism is that the hetu or reasoning relies on the truth of the concomitant relation (smoke $\rightarrow$ fire), which is a matter of empirical observations, when this relation might not be borne out in all locations, or with changing times and technologies, or habits, sufficient to warrant a generalized premise (there is fireless smoke, and smokeless fire). Further, just how are we to go about establishing the vyāpti in matters that go beyond the empirical domain, or even with abstract entities; e.g. A \& B might go together in one domain, but in another logical (possible) world they may contradict and annihilate each other. The conditional counterfactual, if there was no fire there would be no smoke does not always hold true.

Here is another example that relies on modal deduction:

\section{An effect has a cause}

It is not possible for there to be an effect without a cause

As in the case of the pot thrown from clay by the potter

(or, in modern parlance, a watch and the watch-maker),

It is possible that the universe is caused

The universe is an effect (there being no evidence of its being causeless)

Therefore the universe is not without a cause

Like a potter (or watch-maker),

Hence a God-like Creator Being is the cause of the universe. ${ }^{5}$ (Bilimoria, 2011) 
Obviously, the reasoning here is flawed as the effect-to-cause relationship inherent in the particularities of our world - and even that linear causality has been questioned by the Buddhist dialecticians - cannot be generalized to the whole universe for we have not witnessed another universe being produced as an effect sufficient to establish the deduction that 'Therefore the universe is not without cause'. So again, inference has it limits also in terms of its scope, apart from certain palpable defects in reasoning (or the evidence-dependence on perception) that pass off as sound and valid and thereby unwittingly abetting overdetermined or compromised understanding, as in the above examples.

\section{Śabdapramāna (Word)}

The third major source accepted in traditional philosophy is śabda, or 'word', which is applied reliable authority in the form of a person or teacher (āpta) and, more importantly, Āgama, that is the 'Word of Tradition', where 'the word' (śabda) is largely defined with respect to inherited wisdom that is enśrīned in the scriptures and which are traditionally revered or sanctioned. What is embedded in tradition is regarded to be valuable since it is backed by years of experience, or simply wisdom of the learned ones (mahājana-s). The experience of the individual is augmented by the cumulative experience or wisdom of tradition, for which the individual relies on testimony either of scriptures or of others who are entrusted with the preservation of the received traditional wisdom. In this context, words become in a technical sense the medium and possibility of communication.

However, in the hands of the philosophers, it is not tradition per se that comes to be accepted as a distinct source of knowledge, but rather tradition that has been systematized as a result of reasoned enquiry, and which is further validated by a specified set of epistemological criteria (as per the aforesaid third requirement of pramanavāda). Examination, interpretation, evaluation and such aligned functions of pramāna as a general epistemological inquiry are brought to bear equally on tradition as a viable source of knowledge and information about matters that cannot be directly 
perceived, nor for that matter inferred - what we might call the 'transcendental possibilias'. Rigorous criteria were evolved to discern what is acceptable and what is to be rejected under this rubric. The Mīmāṃsā school, which grew out of an exegetical practice of interpreting the sentences of certain portions of Vedic scriptures (the Brāhmanas in main), set the benchmark for what does and what does not fall under the rubric of the pramāna of śabda, exclusively as Śruti, or the 'properly and primarily revealed'. In short, the theoretical underpinning of śabdapramāna - as the more precise articulation of Āgama or 'Tradition' - has its roots in the very early attempts to systematize and justify tradition as knowledge-systems as legitimate and preeminent means of knowing over and beyond, so the argument goes, pratyakșa and anumana. (Bilimoria 1989, 1994, 1997, 2008)

To say a little more on śabdapramāna, since this is the key term of inquiry in this paper, the uniqueness of śabda as a means of knowing lay in its having the capacity to be a special instrument among the aggregate of conditions. In particular, it seemed that śabda has the capacity to elicit knowledge in contexts and circumstances where the other means of knowing (pratyakșa and anumāna especially) fall short or are proven to be less adequate and not particularly informative. The possibilities of communication that words open up, so to speak, and their encapsulative power, were also believed to present certain advantages that are conspicuous by their absence in most other sources that we have discussed.

\section{Swāminārāyaṇa on śabdapramāṇa}

Moving now to the main part of the discussion, we wish to show how this disquisition on the most authoritative pramāna is related to Śrī Swāminārāyaṇa's own philosophy. We shall begin by considering which according to Śrī Swāminārāyaṇa is the most authoritative pramāna, how its authoritativeness is established, and how his position in regard to this differs from, in particular, Śaṅkarācārya's Advaita Vedānta and Rāmānuja's Viśiștādvaita Vedānta. (Bilimoria 1978a) And, finally, we shall dilate on the metaphysical 
consequences that follow as a result of the difference that marks Swāminārāyaṇa's position from among the other epistemological positions that we shall examine.

Taking the cue from Rāmānuja's Viśișțādvaita, to which Śrī Swāminārāyaṇa's own philosophy is closely linked, one would expect the most authoritative pramāna to be śabdapramāna, which as we saw above, underwrites the 'sacrosanct word of a reliable source, particularly the scriptures.' And this is so. Concentrating on the 'scriptures' bit for a while, some questions arise (as is the mind of the imagined pūrvapakșa or adversary): which scriptures? whether one or many? And there is also the issue of whether there is any relation to the scriptures traditionally accepted for their authoritativeness, particularly in respect of Śruti, which was identified with the Vedas in Vedānta, and Smrti texts which are considered to be secondary or derivative vis-á-vis the authority of Śruti, and can - like pratyakșa and anumāna - be overridden by the authority of Śruti. (This is not unlike, to draw from a prosaic example, a court judgment based on the Penal Code or a prior legislation is shown juridically to be ultra virus or in violation of an Article in the Constitution). A further consideration is in respect of the 'origin' of the scriptures - some, like the Mīmaanmsaka believe them to be apauruṣeya (non-personal, authorless, hence without origin); others that they are paurușeya (personal, from a decisive 'revealer' as the author); while others may believe the source to be entirely in the 'inexplicable' realm. Whatever the response, we can perhaps already sense that the matter could be of some contention, at least between Śrī Swāminārāyaṇa and Śañkara's Advaita, perhaps also with the Mīmāṃsā.

Śrī Swāminārāyaṇa's response to the first two questions is clearly stated in his Śikṣāpatri, which will be useful to quote in full:

The four Vedas, Vedānta Sutras by Vyasa, Śrīmad Bhagawata, Śrī Vishnu Sahasra Nama, Śrī Bhagawad Gita (from Mahabharata), the Code of Ethics enunciated by Śrī Vidurji (Vidurniti), Śrī Vasudeva Mahatmya from Vishnu 
Khanda of Skanda Purana, and Yajnavalkya Smriti, are the chief amongst all religious scriptures, and I hold these eight scriptures as authoritative and of special significance. (H. T. Dave, 1974:246)

This list is repeated in Vachanāmrut, the collection of Gujarati discourses of Śrī Swāminārāyaṇa, mentioned earlier and which today is regarded as the most sacred and foundational scripture of the sampradāya. The texts are stated more clearly, thus:

"[Thirdly], one should know the authoritative scriptures of our sampradāy, the names of which are: 1. The Vedas, 2. The Vyās Sutras, 3. The Śrīmad Bhāgwat Purān, 4.

The Vishnu-sahasranām from the Mahābhārat, 5. The Bhagwad Gitā, 6. The Vidurniti, 7. The Vāsudev Māhātmya from the Vishnu-khand of the Skand Purān, and 8.

The Yāgnavalkya Smruti. One should know these eight scriptures." (Vachanämrut Vardtal 18).

Furthermore, you say that with the exception of that Brahma, jivas, ishwars, mãyã, the world, the Vedas, the Shãstras and the Purãns are all illusory. I can neither understand this concept of yours, nor can I accept it. Therefore, please answer what I ask you, and do so by citing only the Vedas, the Shãstras, the Purãns, the Smrutis or the Itihãs scriptures. If, however, you reply quoting the words of some inauthentic scripture, then I will not accept your answer. But, since I have absolute faith in the words of Vyãsji, I will be able to accept your reply if you reply quoting his words." (Gadhadã I-39). ${ }^{6}$

To his detractors Swāminārāyaṇa sternly summons to only "quote a verse from the scriptures of Vyāsji or a verse from the Vedas to prove it. Why these two? Because there is no greater āchārya than Vyāsji. Others who have become āchāryas and have established their sampradāys, have accepted the scriptures written by Vyāsji as authoritative." (Gadhadā III-10)

It appears from H T Dave's translation of Śikșāpatri (and in the Gujarati of both the texts) that 'Vyās Sutra' refers to Vedāntasūtra which in turn is the Viśișțādvaita nomenclature for the Brahmasūtra-s of Bādarānya - one of the key texts in the prasāntha-traȳ or canonical trio. But it is an odd name to give to Bādarānya; again, Vyās is also invoked repeatedly in the Vachanamrut as the author and therefore the supreme authority of the whole gamut of scriptures, including the Vedas. But for all 
intends and purposes at least in the tradition at large Vyās (Veda Vyāsa) remains at best a mythical figure; if not then a legendary auctor to whom the compilation of the epic Mahābhārata is often attributed. (Though we know from recent scholarship and the Pune Critical Edition that the Mahābhārata is not a single text, composed by a single author over one lifetime, but rather it was compiled from various fragments, renditions and variegated versions, classical and vernacular by a compendium of authors, interpolators, interlocutors and reciters scattered across the subcontinent - and hence cannot to be attributed to a single author or even a motley of a particular sampradāyic āśrama or pițha. Also called Veda Vyāsa, he appears in other Smṛti texts and simulations of the epic, as a wise sage, Krishna Dvaipāyana, master of grammatical compositions, and counsellor to existentially aggrieved heroes of the warrior royal clans). If one were to have absolute faith in Vyās (Vyāsa) the range of texts would not go that far. The issue gets little more complicated when we take into account the apaurșeya doctrine - 'of authorless scriptures' - championed by the Mīmāṃāa and accepted by certain of the Vedānta schools - a discussion we return to shortly. Be that as it may, and I leave the matter to the learned sadhu-theologians of the Sampradāya, from whichever Sanstha, to shed some light on for us.

That aside, Śrī Swāminārāyaṇa also accepted Rāmānuja's Bhāṣya (commentary) on the Brahmasūtras (also known as Vedāntasūtra-s) and the Bhagavadgītā as "authoritative for acquiring a comprehensive knowledge of philosophy." (ibid) What is important for our purposes is to note that there is an array of different kinds of scriptural texts that Śri Swāminārāyaṇa admits under the rubric of śabdapramāṇa. The Codes of Law and juridical texts as well as normative mores are also included (scripture numbers 6 and 8 in the list on page 9 [check]). Our main concern here is to discern how his classification of what counts as 'canonical authority' in theological terms differs from those of other Vedāntins, including Rāmānuja. The mention of Rāmānuja is interesting in this context as Swāminārāyaṇa situates himself in the sampradāya or pontifical lineage of Rāmānuja: “So, Rāmānand Swāmi's guru was Rāmānujāchārya, and I am Rāmānand Swāmi's disciple." (Vartal -18) ${ }^{7}$. But of course even though a great ācārya, Rāmānuja does not 
come close to having the status as the greatest of ācārya-s, Vyās. Rāmānuja himself may not believe that his own commentaries carry the same authority and prāmānic weight as the Vedas or the Brahmasūtra-s for that matter do.

It certainly is the case that in Śankara's Advaita not all of the scriptures listed in the Vachanāmrut passages cited above would have been accepted unequivocally to be authoritative; and some in Rāmānuja's school would have been given a secondary or ancillary status. It is interesting that the Pāncarātra is not mentioned in the list $^{8}$; yet Rāmānuja took this scripture seriously, and Yamuna (his predecessor) even argued at length for the canonical character of the Pāncarātra. We shall return to this point again shortly. Most interesting of all is the observation that no ostensive demarcation is made between Śruti and Smrti - a distinction that is very crucial and marked in Advaita (Bilimoria 1978b), but also in Viśisțāanvaita: there is a hierarchy in their ordering and the two cannot be readily conflated. If a distinction is implied by Śrī Swāminārāyaṇa, it is not at all clear. The Mīmāmnsā, of course, is also stridently strong on this very point, and would have rejected all but the 'Four Vedas' as the most authoritative scriptures on the list. Since this is an important debate, we shall outline the basis of the Śruti-Smriti demarcation in the Vedānta schools. Let us move through this issue in a little more detail, beginning with the Advaita view.

\section{The Essence of Śruti}

In Advaita, Śruti is said to be, literally, 'that which is heard', and it applies to those scriptures whose 'revelation' is authoritative for the reason that these scriptures do not depend for their 'origin', and hence for their authenticity, on any personal (paurușeya) source other than Brahman (BSB I.i.3); in that respect they are said to be apaurușeya, non-personal, in the sense that their 'manifestation' precedes any connection with a personal agency, or reason for that matter. Śruti is considered to be superior in validity to the other pramāna-s; indeed it is the supreme pramāna. (Mahadevan 1976: 62) 
Brahman is the source of Śruti, and Śańkara here specifically mentions the Vedas, at once lauding the Vedas as the authoritative means of right knowledge of Brahman; of course, the focus of the revered śāstra-s veers towards the Upanișads or Vedānta as the discussion moves on, and it is made clear that while in matters pertaining to the mundane world perception and inference have validity (prāmāṇya) over Śruti, in matters that are supersensory it is only Śruti that has the final authority or word. By 'word' or śabda one does not have to think of the individual words (pada) of any specific language, but rather the 'essential' aspect of words (śaktam padam) in a composite synthesis that yield a unified sense - viz., as vākya or sentence, which is more important for its semantic structure (vākyārtha, or Śābdabodha) than for its outward 'sign-vehicle' (dhvani, lipi, varnātmaka) which are merely the instruments that help to manifest the 'inner Word' or the word-essence (śabdatattva). (BSB I.iii.28; Bilimoria 1989)

As such, these Words are the ultimate bearers of truth, which are thought to be timeless, inexorable, self-existent (svarūpa-sati), being sui generis, prior to the gods, prior even to the evolute-creation of the world (śrștii), and they also survive the dissolution (pralaya) of the cosmic system.(Śankkara is clear on this point, see under BSB I.iii.28). Thus, these Words are not dependent on human convention for their meaning which is fixed from beginningless time since dependence on human conventions leads to an endless process (as convention depends on a prior convention and so forth). They just exist, and human beings in moments of intense ongoing quest after truth 'hear' them: hence Śruti; the sages who come into contact with these Words are said to 'see' the higher truths, thus they are called rșis or 'seers'. And these Words collectively are identified as the Vedas (from vid, that which is known). Thus the Vedas become sacrosanct by their very nature, and so are said to be Revelation par excellence: we may even say, that they are self-revealed. And when 'uttered' in the voice of the sages, there begins the oral tradition mimesis, recollection. (ibid)

Now the beauty of this notion of authenticity from the point of view of Advaita is that in this way it has argued for an independence of the criteria for the authoritativeness of 
scriptures - being independent of personal defects, attritions, and limitations, linguistic or otherwise. In other words, once the scriptures that are to be the most authoritative are assigned authorship, one implicates an agency, and as all agency is involved in some form of activity, particularly mental (cittavrtti), then one cannot be sure that all possible defects, negligence, bias and error have been eliminated from such a source and its operation. Truth then, has to be handed down first-hand, so to speak, without the necessary intervention of a personal source. In being transpersonal it is the highest possible form of transcendental knowledge.

\section{The Mìmāmsā theory of Śabda and Śruti}

We shall understand the position propounded by Advaita better when we look at its basis in the Mīmāṃsā. According to the Mīmāṃsā, the relation between words and their signification is autpattika or given naturally and seamlessly, and is independent of any agency or convention; Śańkara also affirms this linguistic doctrine (Bilimoria 1994; BSB I.iii.28 ); as such then the validity of the comprehension the words give rise to is due solely to a 'power' - śakti - inherent in the words themselves and is not due to the trustworthy character (āptavacana) of the agency, pronouncing the words, or any such extraneous property (guna). (Śabara-bhāșya I.ii.2-10) The Word, then, has an intrinsic signification, which is due to its own significatory power (śabda-śakti), and therefore is an authority in its own right (Bilimoria 1994). The Vedas, in the Mīmāṃsā view, are the collection of such Words par excellence which is totally independent of any 'conventional' composition, such as, say, would be true of the Smrti (recollected) scriptural words (Bilimoria 1997). The signification of the words of the Vedas are hence not fixed by conventional or intentional mode, whether human or divine, for it is not necessary according to the Mīmāṃsā to postulate such an agency; nor need we presume that an agency is needed for precipitating the fruits of the actions, prescribed imperatives or vidhis and niyogas, and thought-disciplines enjoined in the Vedas; these are accomplished through the efficacious (albeit, deferred) phala or results stemming from 
the correct performance of sacrifice and rituals, though what is known as apūrva - 'an invisible subtle potency' (a conceptual precursor to the 'mechanics of karma'; Jha 1978: 56; Bilimoria 2014) which remains beyond the grasp of all agency.

\section{The Advaita-Vedānta Alternative View}

Advaita accepted this position to a large degree, but condescended to admitting the 'agency' of Iśvara in a second-tier metaphysical configuration descending downwards from the most transcendent concept of Brahman.(Bilimoria 2008: 299) And that too only in so far as a repository (demiurge) was required for transmitting or purveying, as it were, the Vedas from one yuga (cosmic era) to another in the intervening period of dissolution (pralaya) and re-emanation of the world (śrșți-prapañca) again, based on the latent or dormant artha, meaning of the Vedas. The Vedas themselves, right down to the individual alphabets that constitute the collective verbal compositional body qua texts, do not get destroyed nor are they transformed in respect of the essential truths embodied. İ́vara as Brahmā (Prajāpati, hence the personal deity) comes to know the Vedas, first-off at the point of each new 'creation'; he next bequeaths the truths to the rșis and munis (seers and ascetics), to whom the Vedas are disclosed in their 'hearing'. They then pass on what they have 'heard' to the next generation, who in turn pass these on to the subsequent generation, and so on and so forth. At some finite point in history the sages decide to record the Vedas, far orally transmitted utterances, into script form, and so we have the scriptures that we identify as Vedas, but often forgetting their mysterious 'origin' and ancient timeless genealogy. The Vedas will continue through many yugas to come, though the form in which they would be preserved can only be a matter of speculation, as the after-sapiens that may evolve from the present homo sapiens - hence 'post-humans' - that come to inherit them in the next yuga may devise more sophisticated ways of recording and transmitting such teachings. The texts may even be embedded or scripted in more complex grammar and modal thinking, with a 
fully-flashed out logical structure, to which the most sophisticated computers that have been created would fail to serve as a proximate analogue, though computers may be of aid as the humble stencil was in the earliest phases. But, we need not speculate further on this.

Now the Vedas in the sense described above, derive their authoritativeness in being what they are: the eternally existing wisdom-knowledge; the authenticity lies in the Vedas being 'heard' and not on account of their having a supreme 'Creator', who in other traditions or theologies is said to give origin to the scriptures and hands them down to the human race. The 'handing down' or 'revealing' process may be there, as it is during the re-emergence of the world, but this process is not to be identified as one of creation $a b$ initio. It is rather the re-issuing of that which contains its own preservation. It is Î́vara who knows this 'sacred-most secret' and it is Î́vara or the personal form or manifest state (saguna) of Brahman who hands down the scriptures; this is why Lord Krishna says in the Bhagavadgitā, that he is the knower of the Vedas (XV, 15). But from the ultimate point of view (paramārthadrștii), there is no revealing God as there is no creating and controlling Lord whose role we may momentarily entertain from śāstradrșți, scriptural vision, tantamount to lokadrșți, 'people's view' or conventional perception, which is all a result of transcendental illusion, i.e. perceiving Brahman with the power of activity, undergoing transformation, and change and production (māyāśabala), which are not even Brahman's accidental properties or potentia, for Brahman in the pristine unconditioned state is not in need of any such qualias. (BSB II.i.14) Finally, in another form of Advaita, namely that advocated by Bhartrhari, the Word is nothing other, in essence, than the absolute, Brahman Itself - though what we know as 'word' (pada) and use it in language in combination with other words in sentences $(v \bar{a} k y a)$, is a lower-level manifestation of the highest unified word (akhandaśabdah) ${ }^{9}$ that as it were breaks out into conventional diction in 'flashes of meaning' or sphoța. (Vākyapadīya I.1). And so the ultimate in Bhartṛhari's system is Śabda-Brahman (Bhartṛhari 1965). 
As we said earlier, this is a purely 'advaita' (non-dualistic) interpretation, and it is not necessarily agreed to by non-Advaita (Vedānta) thinkers such as Rāmānuja. We have reason to believe that Śrī Swāminārāyaṇa would have taken issue with the position represented above. But, before we go on with this critique, we need to look at the other side of the demarcation viz., Smrti, and how their origins and functions among scriptures are described.

$\underline{\text { Smrti }}$

Smrti refers to a class of scriptures that is identified as 'that which was recollected or remembered'. It is not as independent as the Śruti is, as it is dependent for its truths on those of the Śruti itself. We might say, Śruti is the primary or pre-eminent 'revelation' and Smṛti in a sense is the secondary or derivative 'revelation'. Śankkara compares Śruti to pratyakșa or perception and Smrti to anumāna or inference, which, though a logically an independent form of pramāṇa is materially dependent on pratyakșa for its scope (BSB 1.iii.28) . Now while the Vedas, and more emphatically, the Upanișads, are classed as Śruti, Smrtti would encompass the Codes of Law (e.g. Manusmrti), Itihāsa, the epics of Rāmāyaṇa and Mahābhārata, the Dharmaśāstras, minor Āgamas, and the Darśanaśāstras or the treatises of philosophical schools. But Vedānta has yet another classification under which it incorporates its 'canonical trio', as said a few times earlier, namely, prasthāna-traȳ̄, that comprises the Upaniṣad, the Brahmasūtras (of Bādarāyaṇa), and the Bhagavadgītā; commentaries on these texts by any of the eminent Vedānta ācārya-s would also be accepted as authoritative. These would thus be regarded as the Darśanaśāstra of the particular Vedānta school (another way of invoking the prasthāna-trayī śāstra culture). But it is arguable whether the prasthāna-trayī could replace or become a surrogate authority for the Vedas, which are left out except for the Upanișads (the 'end of the Vedas', hence Vedānta), and so be counted as complete corpus or 'Work of Śruti'. 


\section{$\underline{\text { Rāmānuja }}$}

Now we turn to Rāmānuja's school of Viśișțādvaita, and here we find that Śruti was not given the status it enjoyed in the Advaita-cum-Mīmāṃsā system. No doubt, Śruti is accepted as 'revelation' par excellence, but in Rāmānuja's thinking, there could not be any revelation without the desire and will of the Supreme Being (the saguna aspect of Brahman) to impart such wisdom to his devotee. Thus 'revelation' to Rāmānuja could not be apaurușeya as in Advaita. Words would be inert without the 'breath' as it were, of God that infuses śabda with 'meaning' or significance (and thus also the Ultimate Significance). Hence, for Rāmānuja revelation is through and through paurușeyatva. That is to say, it is personal, but in the sense that it is revelation of (from) the person of God. The highest-wisdom is with Brahman; rather it is the supreme character of Brahman is not formless (nirguna) or indeterminate, but rather saguna or with a determined form, namely as Î́vara or Purușottama. Parabrahman is Purușottama, and it is He who creates and reveals the Vedas. He also retrieves the Vedas during pralaya (world-dissolution), and creates the Vedas for each new prapañca or world-manifestation (Bilimoria and Stansell 2010).

Thus we see that Rāmānuja differs from Śańkara on the point of the 'origin' and status of the Śruti scriptures and how they come to be endowed with the authority they are said to possess; but he also differs on the issue of the status of the Smrti scriptures. Smṛti, such as the Pāñcarātra, in themselves are divinely-inspired scriptures, which bring to light the 'essence' of the Vedas (VSB II.ii.43). Thus Smrti is not relegated to the secondary status as in Advaita, nor are the philosophical and religious ramifications of the Smrti-classed scriptures vis-à-vis Śruti overlooked, as was the tendency in Advaita.

We also have Yamuna, the other great savant of Viśișțādvaita Vedānta (who preceded and most likely influenced Rāmānuja), coming out even more vehemently in support of 
the so-called Āgamas; particularly, again, the Pāncarātra. He argued for the authority of the Pāncarātra Āgama as an authentic śabdapramāna in its own right, on the consideration that it is an independent and self-sufficient means to mokșa or salvation. Yamuna was convinced that Śrīman Nārāyaṇa had Himself promulgated the Pāncarātra, amongst other Āgamas, and he argued against Śankara's refutation of its canonical nature, based apparently on Śankara's misreading of a passage in the Brahmasūtra-s (I.i.3; II.i.39-42). ${ }^{10}$ Thus we see in Yamuna, and following him in Rāmānuja, the incipient change in attitude towards the 'Sacred Scriptures', and consequently a change in the precise nuance and scope of 'revelation', that was to influence Śrī Swāminārāyaṇa in his own disavowal of a view comparable to Śankara's Advaita.

In Viśiștāadvaita understanding, 'revelation' could occur in modes of bhakti or intense devotion, as also in selfless action (karmayoga). One need not be a 'seer' or be versed in jñanna-yoga for the illumination of the soul. Yamuna argues that the Pāncarātra is independent of the Vedas in this very respect, for it is a 'revelation' that was not the mere possession of the seers; and yet it is as much a statement of the same personal God as the Vedas are believed to be. Yamuna thus argues: "The Vedas derive their authority from direct knowledge which originates from a person and must therefore naturally derive from a person. Who can doubt that? For we perceive that words, from their very nature, depend for their composition on some entity that is different from themselves. How else could they exist at all? If it is objected that the significance of the book called the Vedas just consists in this that it does in fact exist as Word though nobody has composed it, then we reply; why, if this were true, then the significance of smoke on a mountain consists in this that it whirls irrepressibly sky-high without fire! It is utterly out of the question." (AP, 19; 1971: 16-17).

However, this stands in contradiction to the Advaita argument that any form of verbal authority must be free from three possible defects-viz., (i) authorship, (ii) defects in transmission through an agency, and (iii) the lack of scriptures' own claim of their nonorigin (i.e. of their beginninglessness). The Viśisțādvaita response to this would be that 
such defects, loss and attrition, which Advaita suspects, is lacking in respect of the Vedic and Âgamic scriptures. The reason given here is that it is gratuitous to suppose that the authorship and the 'agency' of divinity could be in any way defective or lacking in perfection, or compromised, for the divine person, Purușottama, is all knowing, and within him rests dharma and all works (karma), and the fruits (phala) thereof. Secondly, the difficulty in having İśvara transmitting the scriptures would be no more than in trying to conceive the non-personal Brahman as the source of transmission of the Vedas; and thirdly, the authority of scriptures lies very much in the Lord having created and revealed them (VSB I.ii.28). Hence there is no reason to suppose that the scriptures that the Viśișțādvaita delineates for their absolute authority could in any way be defective or could misguide those who study and live and perform by them.

Hence we notice how a fundamental difference arises between the Advaita and the the Viśișțādvaita schools on the question of the authoritativeness of scriptures (śabdapramānya), and how the respective responses make a difference as to which scriptures are acknowledged to have the highest authority, and which as having secondary status only. In Advaita, leaving aside the claim in respect of prasthāna-trayī for a moment, the absolute authority is accorded to Vedas qua Śruti, while to Smṛti only a relative or derivative (i.e. secondary) authority is granted, being supervenient on the authority of Śruti; the former is apaureșeya (non-personal in form), the latter, to some extent, paurușeya as some form of personal agency is involved in the 'revelation', or better, disclosing of Smṛti literature. But when we turn to the Viśișțādvaita school, we notice that the demarcation between Śruti and Smrti is not as radically marked; rather, it appears to have been diluted (Bilimoria 1978b). Furthermore, the distinction between apaureșeya and paurușeya that is the defining point of the distinction and separation between Śruti and Smṛti is not recognized as being set in concrete or inexorable. The reasoning here is that what is true of the Vedas or Śruti is absolutely given by God, while in the case of the former scriptures (Smṛti), divine inspiration (on the part of İ́vara) helps to configure them on the basis of the revelations contained in the Vedas. Yamuna 
explains this difference alluding to the distinction between the Vedas and the Pāncarātra, thus: "The difference lies herein that in the case of the Pāncarātra the sequence is created by an independent person, whereas in the case of the Vedas, a dependent person invariably wishes to repeat the exact sequence which had been laid down before him by students who preceded him. A category of a different degree which is established on the strength of recognition should not be denied." (AP 32; p.27-28) Van Buitenen explains the 'categorical degree' (kramāvantarajāti) as the difference that consists in the making of the sequence, by some human agency, as in the case of the Pāncarātra, and in the unmade character of the sequence in the Vedas (AP, 1971: 128, n61). But this does not detract from the fact that both are dependent on God for their truths and their disclosing.

What clearly emerges, however, from the preceding analyses is that the difference between Śruti and Smrti is less important than is their similarity or synchronicity, as it is Bhagavān Nārāyaṇa who is the final source of all such Scriptures, the so-called preeminently revealed and the secondarily derivative. It could be argued that the same 'Knower of Vedas' also revealed the Bhagavadgittā; hence the Gītā ought to be regarded as Śruti too. Which is probably also why it is taken to part of the prasthāna-trayī; but as we said prasthāna-trayī and Śruti are not coterminous and although Śańkara wrote commentaries on the three seminal texts that comprises the prasthāna-trayi he did not argue for their authoritative supremacy over Śruti: on the contrary, they themselves are considered to be commentarial completion of Śruti, with the Upanișads fulfilling both the role of 'end-point' of Śruti and an auto-commentary. There was no attempt to argue that the Gitā is also therefore a Śruti scripture; perhaps for the reason that in Viśișțādvaita, only those scriptures that were revealed by Nārāyaṇa at the beginning of the world or with creation, are to be called Śruti proper, and those that follow later as Smrti (Bilimoria 1978b). However, since the common denominator of both the classes of scriptures is their paurușeyatva (personally-revealed) character, the distinction pertains not so much to their relative authoritativeness as to their respective antiquity and 
classification.

That is to say, they belong to different periods of history in respect of the kāla or temporal moment of their disclosing; they could even be yugas apart, but that does thereby make their authority different in kind (perhaps only in matters of degrees, details, and applications thereof). Thus we can surmise that according to the Viśsistāandvaita, the criteria of authoritativeness with respect to a scripture, or any verbal testimony, is in its being paurușeyatva (divinely personal), albeit, one that is 'reliable and trustworthy' and which cannot be doubted for its property of divinity (i.e. being divinely inspired, or endowed with the 'breath' of the Divine Principle). In virtue of this we can understand why the Bhagavadgitā is also accorded the special status of being a 'divine revelation', as it was Lord Krishna, who identified himself as Purușottama, who is believed to have revealed the teachings to Arjuna, which Sanjaya is said to have 'heard' in the presence of the perplexed King Dṛtharāșțra.

\section{Śrī Swāminārāyana's Position revisited}

Now we can also see that Śrī Swāminārāyaṇa confronted with this issue would argue against the Śańkara's Advaita's guarded position as he would side more with Rāmānuja's Viśsistâadvaita position (since that is his theological lineage also). We can come to this conclusion by looking at some of the statements made in Śikșāpatri - but also in Vachanammrut - pertaining to the status and role of scriptures, which we have already cited in the beginning, and need not rehearse here. Bringing all this together, we see that Śrī Swāminārāyaṇa avoids the commitment to Śruti as defined in Śankara's Advaita and also in its being rendered as the exclusive source of scriptural authority. Hence the Vedas (the four Vedas) are stressed, but no separate mention is made of the Upanișads even though the Upanișads are part of the later Vedas. The Upanișads appear as part of the prasthanā-trayī, whose purpose is to establish a foundational affiliation for the sampradāya than for settling the question of pramānavada - otherwise, as the Mīmāṃsakas had complained the Buddhists could hold up their own assortment of texts 
as being supremely authoritative by working up a framework akin to the prasthanā-trayī.

Furthermore, as a corollary, it may be noted that the authority of the Vedas is not differentiated in Śrī Swāminārāyaṇa's philosophy from those that Advaita itself would regard to be of secondary nature. These include the Brahmasūtra-s, the number of Smrti scriptures mentioned in Śrī Swāminārāyaṇa's list of authoritative scriptures, such as Śrimad Bhāgavata, which follows after the Brahma- or Vedānta-sūtra-s, and portions of the Purānas (especially Skanda), the Yajñāvalkya-smṛti and Vidurnīti (the Codes of Law, etc.) but not the other texts under Dharmaśāstras (such as Kauțilya's Arthaśāstra). It is also intriguing that the well- regarded Purāṇas, such as the Markaṇdeya Purāṇa, Kurmaand Garuda- Purāna appear not to be part of the authoritative scriptures (although their includion may have been implied). Nor even the epic Rāmāyaṇa that constitutes a major Smṛti scripture in Viśiștādvaita. However, there is some consolation in the Bhagavadgītā being included, which perhaps means that the Gītā was considered to have been revealed rather independently of the Mahābhārata. Indeed, the Gītā, in Śrī Swāminārāyaṇaa's view was revealed by Lord Krishna, who is Parabrahman, Purușottama, to Arjuna, and hence its authoritativeness could not be doubted. But the commentary (bhāṣya) that is to be read as the authentic interpretation of the words of Lord Krishna is that of Rāmānuja. Another commentary of Rāmānuja regarded as authoritative is that on the Vedānta-sutra-s; this was advocated perhaps to undermine the influence of Śankkara's commentaries on the same scriptures. But the very fact that Rāmānuja's bhāṣya (along with the bhāșya on the Bhagavadgītā) is preferred indicates that the sympathies of Śrī Swāminārāyaṇa is more with Viśiștāadvaita than they are with Śankara. ${ }^{11}$ Hence we can explain why in the first place the notion of Śruti prevalent in Advaita in quite that way without being mixed up with non-Śruti scriptures, i.e. as sui generis revelation, does not appear in Śrī Swāminārāyaṇa's philosophy or in the Sampradāya literature; in the second instance, this is plausibly why the demarcation between Śruti and Smriti is not as it is found in Advaita, and to an extent. In Rāmānuja and Yamuna also (even though the latter are arguably expanding the scope of Śruti to encompass Smrti texts as well; nonetheless the categorical distinction if not the 
separation remains in-tact).

In other words, it remains to be explained why even a resemblance of the distinction accepted by both Yamuna and Rāmānuja is not retained or entertained in Śri Swāminārāyanaa's position, and why only a portion of what is generally accepted within the Smṛti genre in most schools of Vedānta is admitted in Śrī Swāminārāyaṇa's śabdapramānya as authoritative? It would appear that such a classification, i.e. as Śruti, Smriti, and consequently, the Śruti-Smriti demarcation, has been elided in Śri Swāminārāyanaaa's system such that even the vestiges found in later Viśițādvaita are not in evidence either. This must be the reason, for on what grounds do we accept the authoritativeness of scriptures such as the Vișnusahasranāma, on par with that of the Vedas? It could not be on chronological grounds, for the Vedas are much earlier than the Vișṇusahasranāma (otherwise included in the Mahābhārata), nor on the basis of content, for the latter is more an eulogy (arthavāda) than a profound prescriptive or 'revelatory' text as the Vedas are said to be.

On the basis of the above remarks, we might, I believe, be justified in describing the movement from the strict adherence of Advaita and the Mīmāmnsā toward a conceptualization of Śruti, to the increasing acceptance of Smṛti and Āgamic scriptures in Viśsistâadvaita for their authoritativeness down to the acceptance of a more varied and diverse class of scriptures for their authority in the philosophy of Śrī Swāminārāyaṇa, as indicative of the gradual liberalization of the meaning of Revelation. P. N. Srinivasachari (1967) makes a remark to this effect (Buitenen: 1971 31; ). As a comment on the theologies of the times this may be a fair statement to make; but does, in truth, Revelation liberalize itself to that extent? The challenge was indeed taken up in Christian (and Jewish) theologies as well, particularly during the Reformation period, whence the stricter catholicus Church split in the middle and the movement known as Protestantism attempted to, rather successfully, wrench open the door to the Church's exclusive monopoly on Biblical Revelation and reinterpret the Gospels and Holy Books in a number of different ways, such that there could be greater access to God's Revelations (through 
other means also, such as History itself, in the life of the pious, and by divine Grace indeed). Śrī Swāminārāyaṇa took up a similar challenge in the aftermath of the more egalitarian and inclusive Bhakti movement, when there was a call to enable the Hindu faith to become more open and accessible to a wider cross-section of the population, and to 'tone-down' the Brahmanical proclivity that have narrowed the reach and scope for centuries the preeminent scriptures of the tradition. And this entailed some decisive re-casting of the theology as traditionally conceived as underpinning the faith itself, the fundamental of which is the pillar of authority - the pramāna or 'measure' on which Tradition's faith is based or derived from. The corollary of this was the water-tight distinction that the darśanic (philosophical-scholastic) protagonists had underwritten into the śabdapramāna, and which yielded an hierarchized scriptology. In light of this shift, Śrī Swāminārāyaṇa delivered the message that Revelation is a continuing and progressive (not a regressive or aberrant) process, for the authority of the scriptures does not depend on their antiquity but rather on the 'source' and content of the scriptures; the closer they are to the divine person (Aksara-Purușottama), the more authentic is their teaching and greater is the degree of their authority. Conversely, since a non-personal indeterminate Brahman higher than the personal Parabrahman is not accepted in the Sampradāya, the exclusive nuance of Śruti and the concomitant status ascribed by Advaita and the Mīmāmsā to the Vedas is no longer admissible in Śrī Swaminaryan's theory of scriptural authority or śabdapramāna.

A further observation may be added to the above. As Parabrahman continually manifests Himself on earth in the form of the avatāra (incarnation) of Viṣnu-Nārāyaṇa, there can be no dearth of 'Revelation' during his earthly times, as each Word He utters is pure Wisdom manifesting itself. Thus, the scriptures that evolve from recording or writing down these words cannot be lacking in authenticity, and hence their authoritativeness cannot be dismissed or ignored tout court. It is not unlike the Christian theologians, inspired by Hegel's Philosophy of History and History of Philosophy, in the eighteenth and nineteenth-centuries, who came to believe that since Jesus Christ has entered and become one with history (human temporal time-line), God's Revelation will 
continue to unfold and be dispensed or disclosed within the contours and trajectories of history itself through the thus historicized body of Christ, or the Geist, to the very end of time. In this light, the followers of Śrī Swāminārāyaṇa have proclaimed Swāminārāyaṇa's own Śikṣāpatri and the Vachanāmrut as authoritative testimony or scriptures of the Sampradāya that are accorded the status of 'Revelation'. This should not, however, mean that 'Revelation' or the revelatory disclosures have ceased here. For, it is conceivable that the Supreme Being can continue to disclose truths unknown to human beings through some medium or 'hearing'. Or, alternatively, that the divine could pace the earth again as another avatāra, or amśa-avatāra (minor incarnation), and disclose once again truths similar to the manner in which Lord Krishna revealed the Bhagavadgītā to Arjuna, but speaking to or rather more in keeping with and relevant for the historical epoch or yuga (or perhaps just in terms of the temporal global conditions) in which this occurs. The two possibilities, for which there is ample textual evidence in the larger Hindu tradition suggestive of their foreseen imminence, are not incoherent to conceive given the framework developed by Śrī Swāminārāyaṇa himself.

Before we conclude from our observations thus far, it would be apt to remark that Śri Swāminārāyaṇa advisedly gave voice to the suggestion that 'Revelation' is an on-going process, that it has not ended, and that there is more that we may learn from 'Revelations' to come or as we remember the future - although we might not be able to say what specific form the future Revelations may or may not take.

I wish to conclude this inquiry with the following reflections. In philosophy it has been a given that a prior commitment to a particular view of the highest pramana is instrumental in molding, as it were, the particular metaphysic that emerges from such a system. But the converse could also be the case: a prior commitment to a specific metaphysic determines the mode and character of the pramāna that is accepted as being the most authoritative. Which comes before which: the bird or the egg? Whichever way one conceives of this problem, presented in the form of a paradox, there are implications for structuring and charting out the authority in epistemic knowledge- 
making terms. The implications of the 'paradox' are not unobvious when we look deeper and consider the difference it would make to Śrī Swāminārāyaṇa's theory of śabdapramāna had he accepted Parabrahman to be essentially nirguna, the formless and indeterminately non-dual absolute as in Śañkara's Advaita metaphysics. For then he would have considered differently the sharp line of control or divide between Śruti and Smriti, and the list proffered in Śikșāpatri (\#93-95) would, I venture to surmise given my argument in the preceding pages, have been quite different. Conversely, had Śri Swāminārāyaṇa accepted the absolute authority of the Vedas, particularly of the principal Upanișads, the concept of the formless Brahman may indeed have played a more prominent role in his theology than it does so. In Śrī Swāminārāyaṇa's theology the Nirguna Brahman of the Upanișads, described in negative terms of neti neti (not thus, not thus), is switched to the positively ontology of Akșara Brahman, arguably without doing full justice to the complexity of the nirguna conception in the Upanișads.

Now even if Śrī Swāminārāyaṇa had accepted Rāmānuja's theology without compromise, then again, we may have seen some semblance of the Śruti-Smriti distinction, which as we said earlier, was not eliminated in Rāmānuja's nor in Yamunācārya's system. But Śrī Swāminārāyaṇa was more persuaded, it seems, by Vallabhācārya's intense personification of the Brahman of Vedānta, combined with the growing popularity of the divine personhood of Lord Krishna of the Bhāgavata, whether manifesting on earth as Nara-Nārāyaṇa, Man-God, Keśava, Aniruddha, Pradyumna, or as Purușottama, the highest among beings. He is believed to be able to lead one to mokșa or liberation directly without the need to rely too ominously on the scriptures: the good Lord's prasāda (beneficent grace) in the spirit of surrender (prapatti) would do the bulk of the job or carry the weight (as that of a mother to a kitten) (Gitābhāșya 481). Nevertheless, at the end of the day, scriptures are necessary in Śrī Swāminārāyaṇa's philosophy, on two counts : a) as instructive wisdom instruments (pramāna) to one on the path, b) as records of the continuing 'Revelation' of the supreme Akșara Brahman.

Finally, it is a moot point that this discussion takes place and continues in the tradition, as it is vitally important for any fledging sampradāya seriously and honestly 
intending to ground its own foundational pillars as it were in the hoary wisdom-platform of Tradition, and lay claim to its own authenticity in respect of the authoritative or canonical texts it adopts and those it rejects, or new ones it introduces. At least, in this way, the sampradāya is perceived to effortfully enter the arena where such theorizing and discursive enunciations are occurring. And if there is genuineness to its intention to both contribute to and learn from past masters, or doyens of the darśanic systems, it will thereby be able to carve out a niché in the cross-traditional disquisition that centers around the character, content and reaches, or excesses of śabdapramāṇa.

Further to this, on our part, as students of philosophy and those of the Sampradāya ${ }^{12}$ (Sampradāyakartā) too, the cross-tradition study of pramāṇavāda and engagement with the question of how to 'measure' that authenticity and authority or canonical character of the school's or sampradāya's accepted or adopted scriptures is critically important, as then one can be better equipped with arguments and conceptual 'know-how' or discursive technē ( $v \bar{a} d a-v i v a \bar{d} d a)$ of how to articulate their position and how to defend the claim of the viability of the order's philosophical theology vis-à-vis other Hindu traditions, or for that matter other theologies more globally. The charge of a narrowly configured or constellated sectarian predilection is therewith obviated, or at least addressed in the fullest light with arguments to the best explanation. 


\section{References}

\section{$\underline{\text { Primary Sources }}$}

Bādarāyaṇa. 1938. Brahmasūtras. Trans. S.K. Balvalkar. Poona: The Bilvakunja Publishing House.

Bharț̣hari. 1965. Vākyapadịya with the Vṛtti, Kāṇ̣a I. Trans. K. A, Subramaniya Iyer. Poona: Deccan College Postgraduate Research Institute.

Jayanta Bhața . 1936. Nyāyamañjarī. Ed. Pt Surya Narayan Shukla, Kashi Sanskrit Series 106. Varanasi: Chowkhamba Sanskrit Office.

Nārāyaṇa Bhaț̣a. 1975. Mānameyodaya (Treatise in Mīmāṃsā). Trans. C. Kunhan Raja and S. S. Suryanarayan Sastri. Madras: Adyar Library and Research Centre, No 105.

Mait. Up = Maitreya Upanișad, In, Eighteen Principal Upaniṣads, ed. A A Limaye and R D Vadekar, Poona: Vaidika Samsodhana Mandala.

Rāmānuja. 1976. Vedāntasūtra-Bhāṣya (VSB), also known as Śrībhāṣya, (Sacred Books of the East series, Vol XLVIII part III, trans. by George Thibaut). Delhi: Motilal Banarsidass.

. 1974. Gìtābhāsya, commentary on the Bhagavadgìtāa, issued as Rāmānuja on the Bhagavadgītā. Trans. J A B van Buitenen. Delhi: Motilal Banarsidass.

RgVeda, see Panikkar below.

Śabara. 1973. Śabara-bhāṣya (on Jaimini Mìmāmsāsūtra), Gaekwad Oriental Series. No. 66. (esp. Vol. I. Adyaya I. III 2, 3, 10; I, i.6, 7, 8) Baroda: Oriental Institute.

Śañkara (Śrī Śamkarācārya). 1941. Brahmasūtra-Śà̇kara-bhāṣya, (BSB), with five commentaries, Ed with trans. Anantakṛ̣ṇa Śāstri, Calcutta: Metropolitan Printing \& Publishing Co. Other editions consulted are: Brahmasütras, with text and translation, by Swami Vireswarananda. Calcutta: Advaita Ashram, 1970. (See also under Ghate); The Brahma-sūtras of Bādarāyaṇa with the Commentary of Śankarācārya, Chapter II Quarter II. Original Sanskrit and English trans. by S. K. Belvalkar, Poona: Oriental Books and Supplying Agency.

Srīnivāsadāsa. Yatīndramatadīpikāa. 1967. Trans. Swami Ādidevānanda. Mylapore: Sri Ramakrishna Math.

Swāminārāyaṇa, Śr̄̄ (also known as Bochasanvasi Śrī Sahajānanda Swami). Śikṣāpatri. 1974 
(1882). In H. T. Dave, Life and Philosophy of Shree Swāminārāyaṇa, UK: George, Allen and Unwin, pp. 236-259. Also consulted: Gujarati version:

https://www.Swāminārāyana.nu/sampraday/shiksha.shtml; English rendition. https://www.Swāminārāyana.nu/sampraday/shiksha.shtml (accessed 30/7/2016)

1819. Vachanāmrut (in Gujarati). Translation Website

http://ravchandbapa.blogspot.com/2016/03/vartal-1-to-20.html; also http://www.anirdesh.com/vachanamrut/index.php?format=trans\&vachno=218 (accessed 1/07/2018) .2010. The Vachanāmrut : spiritual discourses of

Bhagwān Swāminārāyan. Ahmedabad: Swāminārāyaṇa Aksharpith (in English),

Van Buitenen. 1971. See next entry.

Yamuna, Āgama Prāmānyami (=AP). 1971. Translation with notes, by A. B. van Buitenen. Madras: Rāmānuja Research Society.

\section{$\underline{\text { Secondary Sources }}$}

Bilimoria, Purushottama, 1978a, "Schools of Vedānta — a plea from a Vedic point of view', Darshana International (Moradabad), January, Vol. XVIII, No. 1.

,1978b, 'Śruti and Smriti-the Un-vedic demarcation (a Viśiștādvaita point of view), Journal of Dharma '(Bangalore) July—Sept, Vol III. No 3.

, 1980a, 'Perception (pratyakșa) in Advaita Vedānta', Philosophy East and West, January, Vol. xxx, No. 1, pp. 35-44 .

, 1980b, 'Pramānavada — Towards an Indian Theory of Knowledge', Darshana International, April.

, 1989, 'The Idea of Authorless Revelation (Apauruseya) in the Mīmāṃsā'. In, Indian Philosophy of Religion, ed. Roy Perrett, Dordrecht: Martinus Nijhoff/Kluwer Academic Publishers, pp 143-166.

, 1994b, 'Autpattika: The originary signifier-signified relation in Mīmāṃsā and Deconstructive Semiology'. In Mandan Mishra Felicitation Volume, ed. R R Diwedhi. Delhi: L.B.S. Rashtriya Sanskrit Vidyapitha, pp.187-203.

1997, 'Liberating Language: Pårthasårathi Mióra on the Sentence and its Meaning', in India and Beyond Aspects of Literature, Meaning, 
Ritual and Thought, Essays in Honour of Frits Staal (ed. Dick van der Meij,: Kegan Paul), pp. 27-49.

2008. Śabdapramāna: Word \& Knowledge: Testimony in Indian Philosophy, New Delhi: DK PrintWorld, 2011; expanded reprint of 1988 edition with Kluwer Publishers, Dordrecht .

, 2011b, 'Nyāya and Navyanyāya', in Jacobsen, Knut A.; Basu, Helene; Malinar, Angelika and Narayanan, Vasudha (eds), Brill Encyclopedia of Hinduism, Vol III, Leiden: E J Brill, pp. 657-671.

,2014, 'Mantric Effect, Noetics of Supplication, and the Apūrva in the Mīmāmsā̄, in: Sanskrit Studies Volume III (Sanskrit Studies Series of JNU), edited by ShashiPrabha Kumar, New Delhi: DKPrintWorld, pp. 222-247.

Dave, Ramesh, M. 2000. Navya-Viśiștādvaita The Vedānta Philosophy of Śr̄̄ Swāminārāyaṇa. Ahmedabad: Akșara Prakāśana.

Ghate, V.S. 1960. The Vedānta A study of the Brahma-sūtras with the Bhāsyas of Śamkara, Rāmānuja, Nimbārka, Madhva, Vallabha. Pune: The Bhandarkar Oriental Research Institute.

Jha, Ganganatha, 1978, Pūrva-Mìmāmsāa. In its Sources, Varanasi: Banaras Hindu University, 1964.

Mahadevan, T.M.P. 1976. The Philosophy of Advaita. New Delhi: Arnold Heinemann.

Panikkar, Raimundo, 1977, The Vedic Experience: Mantramañjarī - A Mythology of the Vedas for Modern Man and Contemporary Celebration, Berkeley: University of California Press.

Srinivasachari, P. N. 1967. Foreword to Srīnivāsadas̄a 1967.

Srinivasa Chari, S. M., 1976, Advaita and Viśiștādvaita, Delhi: Motilal Banarsidas. , 1999, Philosophy of Vedāntasūtra: Study on the Evaluation of the commentaries of Samkara, Rāmānuja and Madhva, Delhi: Munshiram Manoharlal.

Yajnik, J.A. . Philosophy of Śrī Swāminārāyaṇa, 


\section{ENDNOTES}

${ }^{1}$ A much earlier version of this chapter was published as 'Swāminārāyaṇa and ShabdaPramāṇa' , In New Dimensions in Vedanta Philosophy: Bhagawan Swāminārāyaṇa Bicentenary Commemoration Volume, 1781-1981, ed by Sahajānanda, Ahmedabad: Bochasanwasi Śrī Aksharpurushottam Sansthsa, 1981, pp 150-159. I am grateful to three anonymous reviewers nominated by $J D S$, and to Chirayu Thakkar, for their respective comments that have helped me greatly to improve, update and sharpen the arguments and analysis in this paper.

${ }^{2}$ This was pointed out to me by Chirayu Thakkar and stated expressly with detailed attention to the commentaries by Prof George Cardona at the panel where Bhadreshdas Swami made a plenary presentation on the massive work that he completed in 2007. The 17th World Sanskrit Conference, Vancouver, Canada, 9th July 2018.

3 The Vedānta position is presented in the Vedanta Paribhāṣā of Dharmarāja Adhvarīndra, who lived around mid-17th century, and incorporated much of the epistemologies of Mīmāṃsā and Nyāya, along with their respective criticisms also, into Advaita-Vedānta epistemology. (Edited by S. S. Suryanarayana Shastri, Adyar Research Library series, Madras, 1964.)

${ }^{4}$ Śankara accepts the role of inference and argumentation, which he says even the scriptures make use of, and they lead to greater understanding of Śruti, and are an authentic means of knowing provided inference does not contradict scripture. BSB I.i.2 (Thibaut trans. p 15-16); he also brings in intuition here.

$5 \quad$ It may be mentioned that the materialists (Cārvākas) and the Buddhists - much like Immanuel Kant does much later in Western philosophical theology - raised doubts about the soundness of this argument, in as much as we have not seen the universe to have been 'caused' (as distinct from things within the universe that are admittedly governed by the law of causality), and the example (premise \#7), if proper and appropriate, would need to be about other universes having a grand causal agent (not just for pots and cloths or things within our world); the Mīmāmsakas for their part argued that there is no reason why the universe could not be eternally self-propelled, or alternatively be constructed by a consortium of extremely intelligent super-beings who may have since vanished. (See, Bilimoria 2011b)

6 The official BAPS Swāminārāyaṇa Sanstha website has this to say about Vachanāmrut: "The Holy Scripture of the Swāminārāyaṇa Sampraday. A historical collection of 262 spiritual discourses delivered by Lord Swāminārāyaṇa in the Gujarati language. It is a catechism, filled with infallible logic, startling metaphors and analogies, and divine revelations that provide philosophical and practical answers to the mysteries and questions of life." www.Swāminārāyana,org/scriptures/vachanamrut/. Citation is from http://www.anirdesh.com/vachanamrut/index.php?format=en\&vachno=39; Vachanämrut 68. 
${ }^{7}$ http://www.anirdesh.com/vachanamrut/index.php?format=en\&vachno=218

${ }^{8}$ Though a passing mention is made in the context of vindicating the truth regarding god Vishnu's nature about which the detractors had seemingly raised some doubt. Ibid.

9 Bhartrinhari traces four stages through which vāc or śabda manifests itself-viz., parā, the most subtle, paśyantī, a little less subtle level of manifestation, madhyamā, the middle range to which gods and yogis have access, and vaikharī, the most explicit forms used in verbal transactions, i.e. in language of the common man. Our linguistic behaviour occurs at the vaikhari level, where we grasp meanings in 'flashes' (pratibhā) of semantic wholes (akhandārtha) or gestalt-senses (sphoța). Thus, śabda, in this. sense, applies at all levels, right up to the unmanifest (avyakta) primodial principle of its origin, the absolute itself, Śabda Brahman.

Vākyapadīya I.I. anādinidhanaṃ brahma śabdatattvaṃ yadakșaram vivaratate'rthabhāvena prakriyā jagato yatah.

The Brahman who is without beginning or end, whose very essence is the Word, who is the cause of the manifest phonemes, who appears as the objects, from whom the creation of the world proceeds (Iyer trans 1965).

\section{$1.143 \quad$ Vaikharya madhyamayas ca paśyantyas caitad adbhūtam,} anekatirthabhedayas-trayya vācah param padam.

The parā or highest source of speech ( $v \bar{a} c)$ has threefold stages through which it manifests many forms - viz., vaikharī, madhyamā, paśyantī.

10 For a lengthy discussion on this issue with the various readings of Rāmānuja, Yamuna and others, see the Introduction by J. A. B. van Buitenen in Yamuna's Ägama Prāmānyam (=AP). Also in the same book the preface by R. Rāmānujachari is quite interesting in this regard. And Yamuna's own argument is the same from, at p 95ff. Madhvācārya, in commenting on Brahmasūtra I. i. 3 also stated that the Pāñcaratra is on a par with the Vedas.

11 This is reinforced by a contemporary commentary that has been issued on the Brahmasūtra-s from the Sampradāya, Brahmasūtra-Swaminārāyaṇa-bhāșyam, it would not surprise one to note that it is modeled on Rāmānuja's Śrībhāṣya.

${ }^{12}$ I use Sampradāya (as Sampradāayakartā) with capital S when referring to the named lineage of the Swāminārāyanaa order and he established; and sampradaya with lower case 's' when indicating the generic sense of lineage without singling out any particular order. 